\title{
Quality of life (GIQLI) and laparoscopic cholecystectomy usefulness in patients with gallbladder dysfunction or chronic non-lithiasic biliary pain (chronic acalculous cholecystitis)
}

\author{
M. Planells Roig, J. Bueno Lledó, A. Sanahuja Santafé and R. García Espinosa \\ Institute of General Surgery and Digestive Diseases (ICAD). Clínica Quirón. Valencia, Spain
}

Planells Roig M, Bueno Lledó J, Sanahuja Santafé A, García Espinosa R. Quality of life (GIQLI) and laparoscopic cholecystectomy usefulness in patients with gallbladder dysfunction or chronic non-lithiasic biliary pain (chronic acalculous cholecystitis). Rev Esp Enferm Dig 2004; 96: 442-451.

\begin{abstract}
Objective: the aim of this study was to evaluate the incidence, clinical features and role of laparoscopic cholecystectomy (LC) in patients with chronic acalculous cholecystitis (CAC) in comparison with a control group of patients who underwent cholecystectomy for chronic calculous cholecystitis (CCC).

Material and methods: prospective evaluation of 34 patients with CAC in contrast with 297 patients with CCC.

Outcome measures: clinical presentation, quality of life using the Gastrointestinal Quality of Life Index (GIQLI), usefulness derived from the therapeutic procedure as measured in quality of life units by GIQLI, and clinical efficacy at one year of follow-up.

Results: the incidence of complicated biliary disease was higher in CAC (27\%), in comparison with CCC (13.8\%). The histological study of the excised gallbladder revealed a higher incidence of cholesterolosis associated with chronic cholecystitis in the CAC group (64.9\%). GIQLI showed significant differences between preoperative and postoperative measurements in both groups. The associated usefulness of LC was similar in both groups (73 versus 67.3 per cent), confirming an important increase in quality of life for both categories.

Conclusions: the incidence of CAC is 11 per cent with a high association with cholesterolosis. Quality of life and LC usefulness are similar to those of patients with CCC. Due to the fact that cholecistogammagraphy is a technique not available in daily clinical practice, and that oral cholecystography and dynamic ultrasound are reliable when a positive result is obtained, extended clinical evaluation is still the most reliable indicator for cholecystectomy.
\end{abstract}

Recibido: 17-11-03

Aceptado: 27-01-04.

Correspondencia: M. Planells Roig. ICAD. Clínica Quirón. Avda. Blasco Ibáñez, 14.46010 Valencia. e-mail: mplanells@bsab.com.
Key words: Quality of life. Laparoscopic cholecystectomy. Gallbladder dysfunction. Chronic acalculous cholecystitis.

\section{INTRODUCTION}

Chronic acalculous cholecystitis (CAC) is a controversial clinical condition accounting for 5 to 20 per cent of all cholecystectomies (1-3). Patients refer colic biliary pain but ultrasounds show no stones. Most patients are subjected to multiple and repetitive explorations without reaching a final diagnosis. Diagnostic techniques have included dynamic ultrasonography (DUS), oral cholecystography (OC), and dynamic cholecystogammagraphy (DCG) $(1,4,5)$, although accuracy to predict clinical results remains uncertain (6-9) and surgical indications are still based on clinical grounds (10).

\section{PATIENTS AND METHODS}

Patients included in this study underwent cholecystectomy from 2001 through 2002 and divided into two groups: preoperative diagnosis of chronic acalculous cholecystitis (CAC) and those diagnosed with chronic calculous cholecystitis (CCC).

Similar to previous studies $(1,9)$, chronic acalculous cholecystitis was defined as a heterogeneous group of patients with one of the following criteria: a) typical biliary pain with negative ultrasound examination (performed at least twice) and a clinical diagnosis of gallbladder dysfunction (GBD); b) acute acalculous cholecystitis with ultrasound findings of acute cholecystitis but no stones. In this group of patients, repeated attacks of biliary pain after the cholecystitis episode led to a diagnosis of gallbladder dysfunction; c) acute pancreatitis without ultrasound findings of biliary sludge, stones or gallbladder polypoid lesion (PGBL). In this group, magnetic reso- 
nance cholangiography ruled out common bile duct pathology or periampular lesions. Other causes of pancreatitis were also excluded (chronic alcohol abuse, abdominal trauma, hyperlipidemia or hyperparathiroidism); and d) patients with typical biliary pain or biliary dyspepsia associated with PGBL.

Gallbladder dysfunction (GBD) was defined as an epigastric or right upper quadrant pain with or without dorsal irradiation, typically presenting after oral intake, of variable duration and chronic presentation (at least 3 episodes per month), that usually responded to spasmolytic agents or restricted fat-free diet. All patients included were studied at least twice with ultrasounds, which excluded stones, sludge or PGBL. In this group of patients the following tests were also performed: a) Helicobacter pylori determination (urease tests); b) upper gastrointestinal tract radiographic series or esophagogastroscopy; and c) oral cholecystography or dynamic ultrasounds or both.

Laparoscopic cholecystectomy (LC) was indicated as described elsewere (10) when: biliary symptoms were persistent and chronic or acute cholecystitis or pancreatitis developed, and, in the GBD group, when OC or DUS where positive or, if negative, when a clinical evaluation was considered positive. The latter group of patients was informed of the possibility of persistent symptoms due to a lack of accuracy of diagnostic tests and unavailability of DCG.

OC was performed as usual with fat meal stimulation and gallbladder diameter measurements. It was considered positive when a decrease of more than $50 \%$ was not obtained.

DUS was performed with fatty meal also, and gallbladder kinetics was measured with the following formula: (baseline volume - post-stimulation volume / baseline volume) $x$ 100. As in previous studies, it was considered abnormal when a decrease of more than $50 \%$ was not obtained (11).

LC results were evaluated in the following terms: a) histological findings demonstrating chronic cholecystitis with or without cholesterolosis; b) quality of life decrease as expressed by patients using GIQLI (12) in the preoperative interview. In our study, maximum GIQLI (healthy patients) scores ranged from 159 to 165 , as zero values were excluded in order to identify missing values; c) evaluation of quality of life 3 months after surgery (GIQLI) and an estimation of the usefulness of the surgical procedure, defined as positive when an increase of 20 units in quality of life was reached; and d) clinical follow-up during the first year in order to exclude clinical recurrence, and fitness of diagnosis and therapeutic procedure.

All patients underwent ambulatory laparoscopic cholecystectomy as previously described (13-15).

\section{RESULTS}

Patients included in the study were: 37 patients with CAC and 297 with CCC.
Median age was $44.2 \pm 14.2$ years for CAC in comparison with $55.2 \pm 13.6$ years in the CCC group $(p=0.001)$. Sex distribution was similar for both groups, with a male to female ratio of $1 / 2.7$ in the CCA group and 1/3.3 in the CCC group $\left(\chi^{2}=0.262\right.$, NS $)$. No differences in operating time were found between groups $(42.4 \pm 23.1$ minutes $v s$ 49.9 \pm 23.5 minutes; NS).

Table I shows the diagnoses or clinical presentation of patients with clinical diagnosis of CAC and associated histological findings (chronic cholecystitis versus chronic cholecystitis associated with cholesterolosis).

Table I. Diagnostic categories

\begin{tabular}{lccc}
\hline Diagnostic category & $\begin{array}{c}\text { Clinical } \\
\text { pattern }\end{array}$ & $\begin{array}{c}\text { Histology } \\
\text { chronic } \\
\text { cC }\end{array}$ & $\begin{array}{c}\text { Histology } \\
\text { chronic cC } \\
\text { + cholesterolosis }\end{array}$ \\
\hline BD polypoid lesion & GD 13 & 2 & 16 \\
$\begin{array}{c}\text { Biliary pancreatitis with } \\
\text { negative ultrasonography }\end{array}$ & BP 5 & 1 & 3 \\
$\begin{array}{c}\text { Alithisic acute cholecystitis } \\
\text { WMO associated GD }\end{array}$ & AC 6 & 5 & 1 \\
$\begin{array}{l}\text { Gallbladder dysfunction } \\
\text { Total }\end{array}$ & GD 9 & 5 & 4 \\
\hline
\end{tabular}

$\mathrm{GD}=$ gallbladder dysfunction; $\mathrm{BP}=$ biliary pancreatitis; $\mathrm{AC}=$ acute cholecystitis; $\mathrm{BD}=$ biliary dyspepsia; $\mathrm{CC}=$ cholecystitis

Table II summarizes the clinical presentation in both groups of patients, CAC and CCC. Complicated forms of biliary disease (acute cholecystitis and pancreatitis) are higher in the CAC group (27.0\%) than in the CCC group (13.8\%). Patients who needed hospital admission due to complicated biliary disease were also higher in the latter (27\%) than in the former group $\left(16.5 \% ; \chi^{2}=3.04 ; \mathrm{p}=0.011\right)$.

Table II. Clinical presentation forms

\begin{tabular}{lcc}
\hline History & ACC $(37)$ & LCC $(297)$ \\
Asymptomatic & 0 & $4(1.3)$ \\
Acute cholecystitis & $6(16.2)$ & $22(7.4)$ \\
Hepatic colic $\left.{ }^{*}\right)$ & $22(59.5)$ & $201(67.7)$ \\
Biliary dyspepsia & $5(13.5)$ & $51(17.2)$ \\
Jaundice & 0 & $6(2.0)$ \\
Pancreatitis & $4(10.8)$ & $13(4.4)$ \\
\hline
\end{tabular}

(*) Hepatic colics: simple, repeat or complicated (associates with enzymatic movement).

Associated gastrointestinal symptoms, mainly symptoms of peptic ulcer or gastroesophageal reflux disease, did not show statistically significant differences between both groups [51.4 vs 49.2\%; $\chi^{2}=0.063$, NS].

Functional gallbladder tests were only performed in patients diagnosed with GBD. OC was performed in 13 patients (10 positive). DUS was only performed in 5 (all negative). 
Histological analysis of the excised gallbladders demonstrated chronic cholecystitis in $35.1 \%$ of patients in the CAC group and in $93.2 \%$ in the CCC group. Chronic cholecystitis associated with cholesterolosis was found in $64.9 \%$ of patients in the former group and in $6.8 \%$ of patients in the latter group $\left(\chi^{2}=20.7 ; p<0.0001\right)$.

GIQLI was evaluated in 97 patients. Preoperative value (median) was $119.1 \pm 28.6$ in the CAC group $(n=14)$ in comparison with a postoperative value of $143.1 \pm 24.1$ $(\mathrm{p}<0.01)$. In the CCC group $(\mathrm{n}=83)$ the preoperative value was $128.9 \pm 25.4$ and the postoperative value $146.9 \pm 17.3$. These values were not different from that found in the CAC group of patients ( $p$ values, 0.192 and 0.446 , respectively).

The usefulness of the therapeutic procedure (increase in 20 units in postop minus preop GIQLI value) reached similar percentages in both groups (57.1 vs $42.2 \%$; $\chi^{2}=$ $1.08, \mathrm{NS})$.

Clinical follow-up at 7, 9 and 12 months after the procedure showed a similar results in both groups concerning lost patients (27.0 vs 32.0\%; NS) and asymptomatic patients (cured patients) (73.0 vs 67.3\%; NS). There were no differences in associated morbidity between both groups.

\section{DISCUSSION}

One of the most controversial and frequent dilemmas for surgeons in clinical practice, is what should advise to patients referred for recurrent acalculous biliary pain (16). CAC is a controversial issue since: a) histological diagnosis is usually retrospective; b) some clinical conditions are rather diagnosed instead of CAC, as gallbladder stones, common bile duct stones, Oddi dysfunction, gastroesophageal reflux and irritable bowel syndrome; c) the only reliable preoperative diagnostic tool is dynamic cholecistogammagraphy while oral cholecystography and dynamic ultrasonography remain as second-line diagnostic techniques; and d) clinical resolution of symptoms is not guaranteed.

Although in the past, cholecystectomy was selected for patients with complicated gallstone disease, the feasibility of LC deserves consideration for the treatment of CAC, but keeping in mind that symptomatic relieve will not reach all patients $(3,9,17)$; therefore, the role of $\mathrm{LC}$ in GBD is still controversial.

CAC includes two different conditions: a) true CAC with no findings in US examination (performed at least twice), which includes two different histological categories, chronic cholecystitis and chronic cholecystitis associated with cholesterolosis (the latter not diagnosed by US or OCG). Clinical patterns associated with this condition include: gallbladder dysfunction (GBD) or chronic acalculous biliary pain, acute acalculous cholecystitis and acute biliary pancreatitis (the latter associated with cholesterolosis) (18). Moreover, the incidence of cholestero- losis in patients with a diagnosis of GBD is 0 to 60 per cent $(19,20)$, and a preoperative misdiagnosis of cholesterolosis is not rare as US and/or OCG have a low diagnostic power for this condition (21); and b) CAC associated with PGBL (polypoid gallbladder lesions), most of them an expression of gallbladder cholesterolosis. Clinical presentation includes GBD (acalculous biliary colic) and biliary pancreatitis. Histological studies show cholesterolosis associated with a variable degree of chronic cholecystitis. In the majority of series cholesterol polyps are the most frequent PGBLs $(22,23)$. In this group LC is clearly indicated when biliary symptoms are associated (24) and the typical histological finding is cholesterolosis (25). Surprisingly, most studies about acalculous biliary colic, chronic acalculous cholecystitis or GBD do not include cholesterolosis patients $(8,26)$.

Nevertheless, the usefulness of LC in CAC has been demonstrated in patients with or without associated cholesterolosis (19), including patients with or without impairment of the ejection fraction as demonstrated by DCG

CAC incidence reaches 23 per cent in most cholecystectomy series (1), and the histological diagnosis of CAC is more frequent than previously admitted $(6,7,27)$. Histological findings are similar to those found for gallstones. Cholesterolosis (28) may be diagnosed as small polyps in US examination; as it usually is a flat cholesterolosis, this explains the low sensitivity of US for its diagnosis (21). This makes idiopathic pancreatitis a frequent diagnosis in these patients unless a microscopic biliary examination is carried out. In patients with polypoid cholesterolosis, US diagnosis is feasible although this subgroup of patients belong to PGBLs.

In patients with $\mathrm{CAC}$, a low ejection fraction has been demonstrated and histological studies have revealed chronic cholecystitis, cholesterolosis or no findings $(8,19,30)$. The significance of histological findings is not clear (31), as inflammation extent may not be related to symptoms (32). Moreover, although most patients who benefit from LC have a low ejection fraction in DCG, the group of patients in whom CGD is normal also benefit from LC $(8,19,30-33)$, and in this group the frequency of histological findings is similar. Therefore a histological normal gallbladder may have an abnormal DCG probably due to dyskinesia $(34,35)$. Due to the previously described facts, the selection of patients for surgery based on clinical grounds is still of primary importance $(10,36)$, including groups where such selection is made only on clinical grounds and a single US examination (10).

As far as the presenting clinical picture is a complicated condition, such as acute cholecystitis or acute pancreatitis, indications for surgery is clear (19). Nevertheless, a GBD diagnosis is infrequently considered in patients with symptoms of biliary colic but with negative US examination (17). Most of these patients have epigastric pain or right upper quadrant pain with or without dorsal irradiation, typically exacerbated by meals. Due to their ne- 
gative US examination, most of these patients undergo repeated explorations and are finally diagnosed with irritable bowel syndrome or functional dyspepsia (17).

Therefore, the most relevant fact of CAC (20) is that patients are repeatedly investigated with normal results, and are finally diagnosed by the exclusion of functional dyspepsia with no effective treatment, thus becoming a frustrating condition for patients and doctors alike due to repeat explorations and medical visits without clinical resolution. Moreover, due to a lack of understanding of this disease by medical specialists, surgical indications are controversial in all medical areas related to this problem (surgeons, primary care physicians, etc.), which leads to repeat visits and explorations.

There is scientific evidence that patients with a GBD diagnosis have a functional gallbladder emptying disorder that results in a typical biliary pain $(11,27,37)$. However, this diagnosis requires a dynamic demonstration (11). The underlying disorder may be related to three different disorders: a) Oddi sphincter dysfunction; b) cystic duct syndrome; and c) gallbladder dyskinesia which may be primary or secondary to chronic cholecystitis $(17,38)$. The latter is explained by asynchronous gallbladder contraction with Oddi sphincter relaxation, and it is the source of symptoms in patients with CAC and abnormal DCG.

The most reliable diagnostic tool is DCG $(8,11)$. Nevertheless, due to its complexity and difficult availability in clinical practice, other studies such as dynamic ultrasonography are currently under evaluation $(11,33)$.

Multiple studies have demonstrated the usefulness of LC in patients with GBD with abnormal DCG $(30,33,39)$. Results (17) show that patients with GBD undergoing LC have an important clinical benefit regardless of histological findings. This suggests that histological findings are not solely responsible for the clinical picture, and LC is equally effective in patients with or without underlying histological disease.

The complexity of an accurate preoperative diagnosis of GBD remains a lack of accurate diagnostic tests and their availability.

Oral cholecystography gives information about the gallbladder function, and lack of visualization is related to acute or chronic cholecystitis (20). Moreover, the persistence of contrast 24 hours following the test, as demonstrated by a plain abdominal study, suggests cholesterolosis, and this histological finding accounts for 60 per cent of patients with GBD (19).

Dynamic ultrasonography (DUS) allows a semiquantitative estimation of gallbladder emptying by extrapolating volume changes following stimulation (11). Results using the ellipsoid method are optimal although it has important interobserver and intraobserver variability (11). Moreover, changes in morphology associated or not with emptying and gallbladder secretion are not controlled phenomena that may correlate with false volume determinations $(40,41)$.
Therefore DUS (11) is not correlated to DCG and in GBD patients it may not be of diagnostic value when compared to DCG (11).

While OCG and DUS are poorly correlated, this makes preoperative diagnosis difficult and so it is still necessary to select patients through clinical examination.

In conclusion, the incidence of CAC reached 11.1 per cent of patients undergoing cholecystectomy. The prevalence of associated gastrointestinal symptoms was similar for both groups. Quality of life is similarly affected by both CAC and CCC. Complicated biliary disease and hospital admissions were higher in the group with CAC. In quality of life terms, the usefulness of LC was similar in both groups, thus making its surgical indication reasonable. Histological studies were positive in 100 per cent of patients, with a 64.8 per cent of cholesterolosis, similar to previous studies and higher than in the CCC group. Clinical follow-up (one year) demonstrated the clinical efficacy of LC in the CAC group. Diagnostic tests, OCG and DUS showed heterogeneous results, and LC was indicated mainly on clinical patterns, that is, a GBD diagnosis or previous history of complicated biliary disease (acute cholecystitis or pancreatitis). Therefore, clinical selection remains the most important criterion for surgical selection.

\section{REFERENCES}

1. Chen PF, Nimeri A, Pham QH, et al. The clinical diagnosis of chronic acalculous cholecystitis. Surgery 2001; 130: 578-83.

2. Jones Monaham K, Gruemberg JC. Chronic acalculous cholecystitis: changes in patient demographics and evaluation since the advent of laparoscopy. J Surg Laparosc Surg 1999; 3: 221-4.

3. Reitter D, Aaning HL. Chronic acalculous cholecystitis: reproduction of pain with cholecystokinin and relief of symptoms with cholecystectomy. SD J Med 1999; 52: 197-200.

4. Jones DB, Soper NJ, Brewer JD, et al. Chronic acalculous cholecystitis: laparoscopic treatment. Surg Laparosc Endosc 1996; 6: 114-22.

5. Barron LG, Rubio PA. Importance of accurate preoperative diagnosis and role of adavanced laparoscopic cholecystectomy in relieving chronic acalculous cholecystitis. J Laparoendosc Surg 1995; 5: 357-61.

6. Frasinelli P, Wermer M, Reed JF, Scagliotti C. Laparoscopic cholecystectomy alleviates pain in patients with acalculous biliary disease. Surg Laparosc Endosc 1998; 8: 30-4.

7. Adams DB, Tarnasky PR, Hawes RH et al. Outcome after laparoscopic cholecystectomy for chronic acalculous cholecystitis. Am Surg 1998; 64: 1-6.

8. Fink Bennet D, DeRidder P, Kolozski WZ, et al. Cholecystokinin cholescintigraphy: detection of abnormal gallbladder motor function in patients with chronic acalculous gallbladder disease. J Nucl Med 1991; 32: 1695-9.

9. Westlake PJ, Hernshfield NB, Kelly JK, et al. Chronic right upper quadrant pain without gallstones: does HIDA scan predict outcome after cholecystectomy? Am J Gastroenterol 1990; 85: 986-90.

10. Brosseuk D, Demetrick J. Laparoscopic cholecystectomy for symptoms of biliary colic in the absence of gallstones. Am J Surg 2003; 186: 1-3.

11. Pons V, Ballesta A, Ponce M, Maroto N, Argüello L, Sopena R, et al Ultrasonografía dinámica en el diagnóstico de la disfunción vesicular: fiabilidad de un método sencillo de fácil aplicación clínica. Gastroenterol Hepatol 2003; 26 (1): 8-12.

12. Quintana JM, Cabriada J, López de Tejada I, Varona M, Oribe V, et al. Traducción y validación del Índice de Calidad de Vida Gastrointestinal (GIQLI). Rev Esp Enferm Dig 2001; 93: 693-9. 
13. Serralta A, Bueno J, Sanahuja A, García R, Arnal C, Guillemot M, et al. Learning curve in ambulatory laparoscopic cholecystectomy. Surg Laparosc Endosc Percutan Techn 2003; 12: 320-4.

14. Planells M, Sánchez A, Sanahuja A, Bueno J, Serralta A, García R, et al. Gestión de la calidad total en colecistectomía laparoscópica. Calidad asistencial y calidad percibida en colecistectomía laparoscópica ambulatoria. Rev Esp Enferm Dig 2002; 94: 319-25.

15. Serralta A, García R, Martínez P, Hoyas L, Planells M. Cuatro años de experiencia en colecistectomía laparoscópica ambulatoria. Rev Esp Enferm Dig 2001; 93: 207-10.

16. Dwijen C, Misra Jr, Blossom GB, Fink Bennet D, Glover JL. Results of surgical therapy for Biliary Dyskinesia. Arch Surg 1991; 126: 95760.

17. Yost F, Margenthaler J, Presti M, Burton F, Murayama K. Cholecystectomy is an effective treatment for Biliary Dyskinesia. Am J Surg 1999; 178: 462-5.

18. Parrilla Paricio P, García Olmo D, Pellicer Franco E, et al. Gallbladder cholesterolosis: an aetiological factor in acute pancreatitis of uncertain origin. Br J Surg 1990; 77: 735-6.

19. Kmiot WA, Perry EP, Donovan IA, Lee MJR, Wolverson RF, Harding LK, et al. Cholesterolosis in patients with chronic acalculous biliary pain. Br J Surg 1994; 81: 112-5.

20. Calabuig R, Castilla M, Pi F, Domingo J, Ramos L, Sierra E. Disquinesia vesicular en el cólico biliar alitásico. Rev Esp Enferm Dig 1996; 88: 770-4.

21. Jacyna MR, Bouchier IAD. Cholesterolosis: a physical cause of "functional" disorder. BMJ 1987; 295: 619-20.

22. Damore LJ, Cook CH, Fernández KL, Cunningham J, Elison EC, Melvin WS. Ultrasonography incorrectly diagnoses Gallbladder Polyps. Surg Laparosc Endosc Percutan Tech 2001; 11: 88-91.

23. Yang HL, Sun YG, Wan Z. Polypoid lesion of the gallbladder: diagnosis and indications for surgery. Br J Surg 1992: 79: 227-9.

24. Csendes A, Burgos AM, Csendes P, Smok G, Rojas J. Late follow up of polypoid lesions of the gallbladder Smaller than $10 \mathrm{~mm}$. Ann Surg 2001; 234: 657-60.

25. Bilhartz LE. Cholesterolosis. In: Sleissenger \& Fordtran. Gastrointestinal Disease. Philadelphia: WB Saunders 1993. p. 1860-2.

26. Rhodes M, Lennard TWJ, Farndon JR, Taylor RMR. Cholecystokinin (CCK) provocation test: long term follow up after cholecystectomy. Br J Surg 1988; 75: 450-3.

27. Canfield AJ, Hetz SP, Schriver JP, Servis HT, Hovenga TL, et al. Bi- liary dyskinesia: a study of more than 200 patients and review of the literature. J Gastrointest Surg 1998; 2: 443-8.

28. Berk RN, van Der Vegt JH, Lichtenstein JE. The hyperplastic cholecystoses: cholesterolosis and adenomyomatosis. Radiology 1983; 146: 593-601

29. Rice J, Sauerbrei EE, Semogas P, et al. Sonographic appearance of adenomyomatosis of the gallbladder. J Clin Ultrasound 1981; 9: 3367.

30. Yap L, Wycherley AG, Morphett AD, Toouli J. Acalculous biliary pain: cholecystectomy alleviates symptoms in patients with abnormal cholescintigraphy. Gastroenterology 1991; 101: 786-93.

31. Sunderland GT, Carter DC. Clinical application of the cholecystokinin provocation test. Br J Surg 1988; 75: 444-9.

32. Mackey WA. Cholecystitis without stones. Br J Surg 1934; 22: 275 95.

33. Misra DC, Blossom GB, Fink Bennet D, Glover JL. Results of surgical therapy for biliary diskynesia. Arch Surg 1991; 126: 957-60.

34. Davis GB, Berk RN, Scheible FW, Witzum KF. Cholecystoknin cholecystography, sonography and scintigraphy: detection of chronic acalculous cholecystitis. Am J Roentgenol 1982; 139: 1117-21.

35. Sand JA, Turganmaa VM, Koskinen MO, Makinen AM, Norback JH Variables affecting quantitative biliary scintigraphy in asymptomatic cholecystectomized volunteers. Hepatogastroenterology 1999; 46 : 130-5.

36. Kloiber R, Molnar CP, Shaffer EA. Chronic biliary type pain in the absence of gallstones: the value of cholecystokinin cholescintigraphy AJR 1992; 159: 509-13.

37. Sorenson MK, Fancher S, Lang NP, et al. Abnormal gallbladder nuclear ejection fraction predicts success of cholecystectomy in patients with biliary dyskinesia. Am J Surg 1993; 166: 672-5.

38. Velanovich V. Biliary dyskinesia and biliary crystals: a prospective study. Am Surg 1997; 63: 69-74.

39. Jagannath SB, Singh VK, Cruz Correa M, Canto MI, Kalloo AN. A long term cohort study of outcome after cholecystectomy for chronic acalculous cholecystitis. Am J Surg 2003; 185: 91-5.

40. Radberg G, Asztely M, Moonem M, Svanvik J. Contraction and evacuation of the gallbladder studied simultaneously by ultrasonography and 99mTc-labeled diethyl-iminodiacetic acid scintigraphy. Scand J Gastroenterol 1993; 28: 709-13.

41. Glickerman DJ, Kim M, Malik R, Lee S. The gallbladder also secretes. Dig Dis Sci 1997; 42: 489-91.

\title{
Calidad de vida (GIQLI) y utilidad de la colecistectomía laparoscópica en pacientes con disfunción vesicular o dolor crónico biliar alitiásico (colecistitis crónica alitiásica)
}

\author{
M. Planells Roig, J. Bueno Lledó, A. Sanahuja Santafé y R. García Espinosa \\ Instituto de Cirugía General y Aparato Digestivo (ICAD). Clínica Quirón. Valencia
}

\section{RESUMEN}

Objetivo: evaluar la incidencia, manifestaciones clínicas y el papel de la colecistectomía laparoscópica (CL) en pacientes con diagnóstico de colecistitis crónica alitiásica (CCA) en comparación con un grupo control de pacientes intervenidos por colecistitis crónica litiásica (CCL).
Material y métodos: evaluación prospectiva de 34 pacientes con el diagnóstico de CCA en comparación con un grupo control de 297 pacientes con CCL. En el presente estudio analizamos: categoría clínica de presentación, repercusión de la enfermedad sobre la calidad de vida determinada mediante el Gastrointestinal Quality of Life Index (GIQLI), cálculo de la utilidad de la intervención terapéutica (incremento de unidades de calidad de vida) me- 
diante el GIQLI y efectividad clínica del procedimiento al año de la intervención.

Resultados: la incidencia de enfermedad biliar complicada fue superior en el grupo de CCA (27\%) en comparación con el de CCL (13,8\%). El análisis histológico reveló una incidencia de colesterolosis asociada a colecistitis crónica más alta en el grupo de CCA (64,9\%). La determinación del GIQLI permitió evidenciar diferencias significativas entre el preoperatorio y el postoperatorio en ambos grupos de pacientes siendo la utilidad del procedimiento similar percentualmente en ambos grupos (73 vs 67.3\%) implicando una importante mejoría en la calidad de vida de ambos grupos derivada de la intervención terapéutica.

Conclusiones: la incidencia de CCA es del 11 por cien en nuestro ambiente con una elevada asociación a colesterolosis en el examen histológico. La repercusión sobre la calidad de vida es comparable a la de la CCL siendo la utilidad de la colecistectomía laparoscópica similar. Dado que la colecistogammagrafía no es un método asequible en la práctica clínica diaria y que la colecistografía oral y la ecografía dinámica son herramientas útiles sólo cuando se obtienen resultados positivos, la evaluación clínica exhaustiva de los pacientes sigue siendo la base que permite la indicación de la CL sin temor al fracaso.

Palabras clave: Calidad de vida. Colecistectomía laparoscópica. Disfunción vesicular. Colecistitis crónica acalculosa.

\section{INTRODUCCIÓN}

La colecistitis crónica alitiásica (CCA) es una entidad controvertida que supone el 5 al 20 por cien de las colecistectomías practicadas (1-3). Los pacientes sufren de dolor biliar aunque los estudios ecográficos son negativos. Los múltiples intentos de obtener un algoritmo objetivo clínico y diagnóstico han fracasado. La mayoría de los pacientes son sometidos a múltiples y repetitivas exploraciones sin obtener un diagnóstico apropiado. Entre estos estudios diagnósticos se han incluido la ultrasonografía dinámica (USD), la colecistografía oral y la colecistogammagrafía dinámica (CGD) $(1,4,5)$; sin ambargo, la fiabilidad de todos ellos en relación a la predicción del resultado clínico es incierta (6-9) y, en consecuencia, la indicación quirúrgica se basa aún en el cuadro clínico (10).

El propósito de nuestro estudio fue el análisis de los resultados obtenidos por nuestro grupo en comparación con los pacientes intervenidos por colecistitis crónica litiásica (CCL).

\section{PACIENTES Y MÉTODOS}

Se incluyeron en este estudio dos grupos de pacientes intervenidos durante el periodo 2001-2002: pacientes con diagnóstico preoperatorio de colecistitis crónica litiásica (CCL) y pacientes con el diagnóstico preoperatorio de colecistitis crónica alitiásica (CCA).

Al igual que en estudios previos $(1,9)$ definimos como colecistitis crónica alitiásica (CCA) a un grupo heterogéneo de pacientes con las siguientes características: a) clínica de dolor hepático típico con ecografía hepatobiliar (practicada al menos en dos ocasiones) sin hallazgos patológicos y, por tanto, con diagnóstico clínico de disfunción vesicular (DFV); b) sintomatología de colecistitis aguda con ecografía hepatobiliar sin evidencias de litiasis pero con hallazgos radiológicos de colecistitis aguda (imagen en doble carril, distensión vesicular y Murphy ecográfico positivo). Estos pacientes fueron ulteriormente diagnosticados de disfunción vesicular (DFV) dada la persistencia del cuadro clínico de dolor hepático alitiásico; c) cuadro clínico de pancreatitis con elevación de la amilasa y/o amilasuria pero sin evidencia ecográfica de litiasis, barro biliar o lesión polipoidea en la vesícula biliar (LPVB). En este subgrupo, la exploración asociada fue la colangiorresonancia a fin de descartar patología de la vía biliar o periampular a la vez que de coledocolitiasis. En este grupo de pacientes se excluyeron otras causas de pancreatitis alitiásica tales como como: etilismo, traumatismo abdominal, hiperparatiroidismo, hiperlipemia o páncreas divisum; y d) pacientes con clínica de cólico hepático típico y/o de dispepsia biliar asociada a hallazgos ecográficos de LPVB.

Se definió como disfunción vesicular (DFV) a la presencia de dolor en epigastrio y/o en hipocondrio derecho con o sin irradiación dorsal de presentación postprandrial, duración variable y presentación crónica (al menos 3 episodios por mes), que respondía a los espasmolíticos o disminuía su frecuencia de presentación cuando el paciente seguía una dieta exenta de grasas (dieta de protección hepatobiliar). Todos los pacientes incluidos en esta categoría diagnóstica presentaban al menos 2 estudios ecográficos hepatobiliares con demostración de ausencia de litiasis biliar o lesiones polipoideas de vesícula biliar (LPVB). En este grupo de pacientes se practicaron como pruebas diagnósticos asociados: a) la prueba de la ureasa para la demostración del Helicobacter pylori; b) estudio radiológico baritado del tracto digestivo superior y/o esofagogastroscopia cuando estuvo indicada; y c) colecistografía oral o ultrasonografía dinámica, o ambas. Tan sólo en un caso se pudo practicar colecistogammagrafía dinámica.

La indicación de CL incluyó como en otros estudios (10): los síntomas biliares persistentes, el desarrollo de formas complicadas de CCA, tales como la colecistitis aguda y la pancreatitis biliar y, en el grupo de DFV, la demostración de colecistografía oral patológica y/o ecografía funcional patológica o bien la persistencia del cuadro clínico estricto con respuesta a espasmolíticos, a pesar de que los exámenes colecistográficos o ultrasonográficos sean negativos. Este último grupo de pacientes fue convenientemente advertido sobre la posible ineficacia de la intervención dado la inexistencia de exámenes complementarios fiables en la actualidad, con la excepción de la colecistogamagrafía, que no es asequible en la práctica clínica diaria. 
La colecistografía oral se realizó según técnica habitual con comida de estímulo graso y medición de los diámetros vesiculares. Se consideró que la prueba era anormal cuando estos diámetros no descendieron a menos del $50 \%$ de los iniciales.

La ecográfia funcional se practicó de forma similar, con estímulo alimenticio graso. El vaciamiento vesicular se calculó mediante la siguiente fórmula:

(Volumen basal - Volumen postestímulo/ volumen basal) x 100 .

En ausencia de un valor límite de normalidad universalmente aceptado, se decidió, al igual que en estudios previos (11), y de manera arbitraria, estimar como anormal un vaciamiento inferior al $50 \%$.

Se evaluó el resultado de la intervención terapéutica en función de los siguientes parámetros: a) examen histológico de la pieza con demostración de hallazgos de colecistitis crónica con o sin colesterolosis asociada o eventualmente ausencia de alteraciones histológicas; b) repercusión sobre la calidad de vida expresada por el paciente según los criterios del "Gastrointestinal Quality of Life Index" (GIQLI) (12) valuado en el preoperatorio con el fin de objetivar el nivel de repercusión de la enfermedad sobre el paciente. En nuestro grupo, la puntuación máxima del GIQLI (pacientes sanos) es de 159 a 165 (en proporción a los valores considerados como sanos en publicaciones previas) dado que se excluyó en su momento el valor cero a fin de diferenciar los valores perdidos para el análisis; c) evaluación de la calidad de vida a los 3 meses de la intervención terapéutica, permitiendo el cálculo de la utilidad de la intervención definida esta como positiva cuando existió un incremento en al menos 20 unidades en el GIQLI con el fin de objetivar la ganancia en calidad de vida y por tanto la adecuación de la intervención terapéutica; y d) deguimiento clínico a un año a fin de evidenciar la ausencia de recurrencia del cuadro clínico, la curación clínica del paciente y lo acertado del diagnóstico y tratamiento realizado.

Todos los pacientes fueron sometidos a colecistectomía laparoscópica de forma ambulatoria (CLA) siguiendo el método que hemos descrito previamente (13-15).

\section{RESULTADOS}

Se incluyeron en el estudio 37 pacientes con diagnóstico clínico-ecográfico de CCA y 297 con CCL. La edad media fue de 44,2 $\pm 14,2$ años en el grupo de CCA y de $55,2 \pm 13,6$ años en el grupo de CCL $(p=0,001)$. La distribución por sexo fue similar en ambos grupos con una relación varón/hembra de 1/2,7 en el grupo de CCA y de $1 / 3,3$ en el grupo de CCL (NS). No hubo diferencias en cuanto a la duración de la intervención $42,4 \pm 23,1$ minutos en el primer grupo frente a $49,9 \pm 23,5$ minutos en el segundo $(\mathrm{p}=0,069)$.

En la tabla I se muestra la categoría diagnóstica y/o presentación clínica de los pacientes diagnosticados de
Tabla I. Categorías diagnósticas

\begin{tabular}{lccc}
\hline Categoría diagnóstica & $\begin{array}{c}\text { Patrón } \\
\text { clínico }\end{array}$ & $\begin{array}{c}\text { Histológico } \\
\text { ctts. crónica }\end{array}$ & $\begin{array}{c}\text { Histológico } \\
\text { ctts. crónica } \\
\text { + colesterolosis }\end{array}$ \\
\hline Lesión polipoidea de VB & $\begin{array}{c}\text { DFV } 13 \\
\text { DB } 5\end{array}$ & 2 & 16 \\
$\begin{array}{l}\text { Pancreatitis biliar con } \\
\begin{array}{c}\text { ecografía negativa } \\
\text { Colecistitis aguda } \\
\text { alitiásica C/S DFV asociada }\end{array}\end{array}$ & PB 4 & 1 & 3 \\
$\begin{array}{l}\text { Disfunción vesicular } \\
\text { Total }\end{array}$ & DFV 9 & 5 & 1 \\
\hline
\end{tabular}

$\overline{\mathrm{DFV}}=$ disfunción vesicular; $\mathrm{PB}=$ pancreatitis biliar; $\mathrm{CA}=$ colecistitis aguda; $\mathrm{DB}=$ dispepsia biliar. CTTS = colecistitis

CCA junto a los hallazgos histológicos (colecistitis crónica, colecistitis crónica asociada a colesterolosis).

En la tabla II se muestra la presentación clínica (categoría diagnóstica) en ambos grupos de pacientes. Debemos resaltar que la frecuencia de patología biliar complicada (colecistitis aguda, pancreatitis biliar) era superior en el grupo de CCA $(27,0 \%)$ que en el de CCL $(13,8 \%)$. $\mathrm{El}$ porcentaje de pacientes que requirieron ingreso previo debido a que la enfermedad biliar estaba complicada mantuvo la misma distribución ( 73 vs 13,8\%; $\chi^{2}, 3,04 ; \mathrm{p}=$ 0,011). La frecuencia de síntomas gastrointestinales asociados, fundamentalmente de tipo ulceroso o de reflujo gastroesofágico, no mostró diferencias significativas entre los dos grupos $\left(51,4\right.$ vs $49,2 \% ; \chi^{2}, 0,063$, NS).

Tabla II. Formas de presentación clínica

\begin{tabular}{lcc}
\hline Antecedentes & CCA $(37)$ & $C C L(297)$ \\
Asintomática & 0 & $4(1,3)$ \\
Colecistitis aguda & $6(16,2)$ & $22(7,4)$ \\
Cólico hepático $\left(^{*}\right)$ & $22(59,5)$ & $201(67,7)$ \\
Dispepsia biliar & $5(13,5)$ & $51(17,2)$ \\
Ictericia & 0 & $6(2,0)$ \\
Pancreatitis & $4(10,8)$ & $13(4,4)$
\end{tabular}

(*) Cólicos hepáticos: simples, de repetición o complicados (asociados a movimiento enzimático).

Se practicaron exploraciones funcionales de la vesícula biliar en aquellos pacientes con diagnóstico estricto de DFV y que por tanto no presentaron ninguna complicación (CA o PB) o que presentaron como hallazgo ecográfico una LPVB. Se practicaron 13 colecistografías orales de las cuales 10 fueron positivas y 3 negativas. Sólo se practicó ecografía dinámica en 5 casos, siendo el resultado negativo en todos ellos.

El estudio histológico demostró colecistitis crónica en el $35,1 \%$ de los pacientes del grupo CCA y en el 93,2\% de los pacientes del grupo CCL y colesterolosis asociada a colecistitis crónica en el $64,9 \%$ del primer grupo y en el $6,8 \%$ del segundo grupo $\left(\chi^{2}, 20,7 \mathrm{p}<0,0001\right)$. 
El GIQLI fue evaluado en 97 pacientes del conjunto analizado. En los pacientes del grupo de CCA (14) el valor preoperatorio fue de $119,1 \pm 28,6$ en comparación con un valor postoperatorio de 143,1 $\pm 24,1$ ( $\mathrm{p}<0,01)$. En los pacientes con CCL (83) el GIQLI preoperatorio fue de $128,9 \pm 25,4$ y el postoperatorio de $146,9 \pm 17.3$. Estos índices no se diferenciaron estadísticamente de los hallados en el grupo de CCA ( $p=0,192$ y 0,466 , respectivamente).

La utilidad de la intervención terapéutica, definida como un incremento igual o superior en 20 puntos al GIQLI preoperatorio fue percentualmente similar en los 2 grupos, (57,1 vs 42,2\%; $\left.\chi^{2}, 1,08 \mathrm{p}=0,297\right)$.

El seguimiento a los 7,9 y 12 meses tras la intervención mostró un porcentaje de pacientes perdidos para el mismo similar en ambos grupos (27,0 vs 32,0\%; NS), siendo el resultado de la intervención terapéutica satisfactorio (paciente asintomático) en el $73 \%$ frente al $67,3 \%$, respectivamente. No se ha evidenciado diferencia en cuanto a morbilidad entre ambos grupos.

\section{DISCUSIÓN}

Uno de los dilemas más complejos y frecuentes para el cirujano es decidir qué consejo dar a un paciente remitido por presentar síntomas recurrentes de cólico hepático cuando la ecografía no demuestra la presencia de litiasis biliar (16).

La colecistitis crónica alitiasica (CCA) es una entidad clínica sometida a controversia, residiendo esta en varios aspectos: a) el diagnóstico histológico es necesariamente retrospectivo; b) hay un conjunto de enfermedades que originan síntomas clínicos similares que frecuentemente son diagnosticados antes de la intervención. Entre estas figura la colelitiasis, la coledocolitiasis, la disfunción del esfínter de Oddi, el reflujo gastroesofágico y el síndrome de colon irritable; c) no existe un método diagnóstico, salvo la colecistogammagrafía dinámica (CGG), que permita obtener un diagnóstico preoperatorio fiable, dado que los métodos utilizados en la práctica clínica (colecistografía oral y ecografía dinámica) no lo son; y d) la resolución de los síntomas con la colecistectomía no es absolutamente segura.

Aunque en el pasado la colecistectomía estaba reservada para pacientes con enfermedad litiásica complicada, la eficacia y seguridad probada de la CL obliga a que esta técnica sea considerada en el tratamiento de la CCA, si bien es fundamental que el clínico sea consciente de que la CL en la CCA no asegura el incremento sintomático $(3,9,17)$. Por este motivo, el papel de la CL en el tratamiento de la disfunción vesicular sigue sin ser aceptado universalmente.

Bajo la denominación de CCA se incluyen dos entidades diferentes: a) la CCA verdadera, en la que no hay evidencia alguna de patología en el estudio ecográfico (al menos dos estudios con un intervalo superior a dos meses). En la CCA se incluirían a su vez otras dos entidades histológicas diferentes, la colecistitis crónica estricta y la colecistitis crónica asociada a colesterolosis (esta última no diagnosticada por los estudios ultrasonográficos o por la colecistografía oral). El patrón clínico de esta entidad incluye: la disfunción vesicular (DFV) o cólico biliar alitiásico, la colecistitis aguda alitiásica y la pancreatitis (esta última asociada a colesterolosis) (18). Debe tenerse en cuenta que la incidencia de colesterolosis en los pacientes con cuadro clínico de DFV oscila entre el 0 y el 60 por cien $(19,20)$ y la ausencia de diagnóstico preoperatorio de colesterolosis no es infrecuente, ya que el rendimiento diagnóstico de la ecografía y/o la colecistografía es bajo (21) en esta situación; b) la CCA asociada a LPVB (lesiones polipoideas de vesícula biliar) es expresión, en la mayoría de los casos, de una colesterolosis vesicular cuya traducción clínica comprende la DFV (cólico hepático alitiásico) y la pancreatitis biliar como más comunes y cuyo sustrato histológico es la colesterolosis asociada o no a mayor grado de colecistitis crónica. En la mayoría de las series, los pólipos de colesterol constituyen las causas más frecuentes de LPVB $(22,23)$. En este grupo está claramente aceptada la colecistectomía cuando existen síntomas biliares asociados (24) y el hallazgo histológico típico es la colesterolosis (25). Sorprendentemente la mayoría de los estudios sobre cólico hepático alitiásico, colecistitis crónica alitiásica y/o DFV no incluyen el análisis de pacientes con colesterolosis $(8,26)$. En cualquier caso, la utilidad de la CL en el ámbito de la CCA ha sido demostrada en pacientes con o sin colesterolosis vesicular asociada a DFV (19), incluyendo la mejoría clínica de pacientes con o sin alteración de la fracción de eyección medida por la colecistogammagrafía dinámica (CGD). En el grupo de pacientes con colesterolosis, el porcentaje de alteración de esta es del 80 por cien.

La incidencia media de CCA en series de colecistectomías es del 23\% (1) si bien, desde el punto de vista histológico, la CCA es una condición más frecuente de lo que se piensa $(6,7,27)$. El cuadro histológico es similar al de la colecistitis crónica asociada a colelitiasis. La colesterolosis (28) puede dar la imagen de pequeños y múltiples pólipos en la ecografía, pero dado que usualmente es plana, se explica la baja sensibilidad de la ecografía para su detección (21), lo que conlleva la etiqueta, en pacientes con pancreatitis, de pancreatitis idiomática. En los casos en que la colesterolosis adopta la forma polipoide, es factible su detección ecográfica o colecistográfica (29), pero estos casos forman parte del grupo de LPVB.

En los pacientes con cólico biliar alitiásico se ha demostrado que la fracción de eyección de vaciamiento vesicular está disminuida y el examen histológico ha mostrado la existencia de colecistitis crónica, colesterolosis o bien ausencia de hallazgos histológicos anormales $(8,19,30)$. La significación de los hallazgos histológicos en la CCA no es clara (31), ya que el grado de inflama- 
ción puede no estar relacionado con los síntomas (32). Por otra parte, aunque la mayoría de los pacientes que se benefician de la CL presentan una alteración de la contractilidad vesicular (en los estudios en que se ha practicado colecistogammagrafía), el grupo de pacientes con contractilidad normal también se beneficia de la CL en un porcentaje no desdeñable $(8,19,30-33)$. En este grupo de pacientes, la frecuencia de alteraciones histológicas es similar. Por tanto, una vesícula histológicamente normal puede presentar una baja FE, debido presumiblemente a discinesia $(34,35)$. Por esta razón, la selección de casos candidatos a cirugía basada en el cuadro clínico es aún hoy en día de considerable importancia $(10,36)$ existiendo grupos en los que la selección de pacientes para cirugía se basa en la clínica y un solo estudio ecográfico (10).

En tanto el cuadro clínico de debut sea una categoría complicada como colecistitis aguda o pancreatitis, el manejo de estos pacientes no representa ningún problema, ya que la indicación quirúrgica es clara (19). Sin embargo, el diagnóstico de DFV es infrecuentemente considerado en pacientes con síntomas sugestivos de cólico hepático en los que la ecografía no evidencia colelitiasis (17). La mayoría de estos pacientes se quejan de epigastralgia o dolor en HD, con o sin irradiación a escápula, exacerbado por la ingesta de alimentos (típicamente postprandial). Debido a la negatividad de la ecografía, muchos de estos pacientes son sometidos a múltiples y repetidas exploraciones sin que ninguna de ellas demuestre hallazgos patológicos y son incluidos en el grupo diagnóstico de síndrome de intestino irritable o de dispepsia funcional (17).

Por tanto, la mayor relevancia de la CCA (20) reside en que los pacientes entren en una secuencia de exploraciones múltiples y repetidas con resultados variables, pero generalmente normales. Finalmente, son diagnosticados por exclusión de dispepsia de tipo funcional y, en consecuencia, no reciben tratamiento efectivo alguno. Se trata por tanto, de una enfermedad frustrante para el médico (por su desconocimiento) y para el propio paciente, que requiere repetidas consultas médicas, numerosas exploraciones complementarias pero sin que ello solucione el problema clínico del paciente. Aún más, debido a la frecuente falta de conocimiento entre los profesionales médicos sobre la CCA, la indicación quirúrgica es puesta en duda por estos en todas las áreas de especialidad relacionadas (cirujanos, radiólogos, gastroenterólogos, etc.) generando nuevas y repetidas consultas médicas y nuevas re-exploraciones.

Existen evidencias científicas crecientes que indican que los pacientes diagnosticados de DFV tienen una alteración funcional que determina un anormal vaciamiento vesicular, que puede provocar un dolor abdominal que remeda al cólico biliar típico $(11,27,37)$ y que precisa para su diagnóstico la demostración de que existe tal trastorno del vaciamiento (11). La alteración funcional causante del cuadro clínico puede ser ocasionada a su vez por tres entidades diferentes: a) disfunción del esfínter de Oddi; b) síndrome del conducto cístico; y c) dismotilidad o discinesia vesicular que a su vez puede ser intrínseca o primaria o secundaria a colecistitis crónica $(17,38)$. Esta última es debida a la contracción de la vesícula biliar asíncrona con la relajación del esfínter de Oddi y es el origen de los síntomas que presentan los pacientes con CCA y una colecistogammagrafía con una FE menor del $35 \%$.

La prueba de elección en el diagnóstico de la DFV es la colecistogammagrafía dinámica $(8,11)$. Sin embargo, debido a su complejidad y a su difícil acceso en la práctica clínica, otras alternativas, como la ultrasonografía dinámica, están siendo estudiadas y valoradas $(11,33)$.

Múltiples estudios han demostrado la eficacia de la CL en pacientes con DFV y CGG demostrativa de disminución en la fracción de eyección $(30,33,39)$. Los resultados (17) indican que los pacientes con DFV sometidos a CL mejoran llamativamente independientemente del resultado histológico, lo que sugiere que no sólo la alteración histológica es la responsable del cuadro clínico. La eficacia de la CL es igual en los pacientes con DFV y hallazgos histológicos patológicos que en el grupo de pacientes en que la histología no demuestra cambios patológicos.

La complejidad del diagnóstico preoperatorio de CCA/DFV reside en la falta de pruebas clínicamente utilizables y fiables. La colecistografía oral informa sobre la función vesicular, dado que la ausencia de opacificación de esta se relaciona con la existencia de una colecistitis aguda o crónica (20). Aún más, la visualización de la misma a las 24 horas de practicada en una radiografía simple de abdomen se asocia a colesterolosis y esta entidad se encuentra en el 60 por cien de los pacientes con DFV (19). La ecografía funcional (USD) permite una valoración semicuantitativa del vaciamiento vesicular por extrapolación de los cambios de volumen que causa el estímulo colecistokinético (11). Los resultados utilizados mediante el método elipsoide son los óptimos en la práctica de la USD, aunque está sometida a una variabilidad importante tanto inter- como intraobservador (11). Además, los cambios en la morfología vesicular asociados o no a vaciamiento, la propia secreción y los episodios de vaciamiento y rellenado vesicular son fenómenos incontrolables que pueden falsear las medidas de volumen con USD $(40,41)$. Por tanto, la fiabilidad de la USD (11) no es ni mucho menos pareja a la CGD y cuando es realizada según una técnica simple, carece de valor diagnóstico en la disfunción vesicular tomando a la CGD como prueba de referencia. A su vez, la correlación entre la USD y la colecistografía oral es baja lo que ocasiona una dificultad diagnóstica objetiva que obliga a recurrir al cuadro clínico para establecer la indicación quirúrgica.

De nuestro estudio se pueden derivar las siguientes conclusiones: a) la incidencia de CCA fue del $11,1 \%$, sensiblemente inferior a la publicadas en otras series quirúrgicas; b) la prevalencia de síntomas gastrointestinales asociados fue similar en los dos grupos analizados; c) el detrimento en calidad de vida secundario a CCA es simi- 
lar al generado por la CCL cuando se utiliza el GIQLI para determinar la repercusión de la enfermedad; d) el porcentaje de pacientes con enfermedad biliar complicada y/o que precisaron ingreso hospitalario por categoría de enfermedad biliar complicada fue superior en el grupo de pacientes con CCA; e) la utilidad de la intervención terapéutica medida mediante la diferencia del GIQLI prey postoperatoria es similar en ambos grupos derivándose lo apropiado de la indicación terapéutica; f) el examen histológico mostró alteraciones en el 100\% de los casos siendo la incidencia de colesterolosis del $64,8 \%$, valor similar a estudios previamente publicados y superior al grupo de CCL; g) el seguimiento a un año demostró la eficacia clínica de la CL en los pacientes con CCA; y h) la colecistografía y la ecografía dinámica mostraron resultados heterogéneos e incluso contrarios, por lo que la indicación de CL se basó en último lugar en las manifestaciones clínicas de DFV o bien en los antecedentes de colecistitis o pancreatitis biliar y, por tanto, la selección clínica continua vigente al igual que otros autores. 